To cite this article: Beyan C, Beyan E. Editöre mektup: Vücut kitle indeksi ile ortalama trombosit hacmi arasında herhangi bir ilişki bulunmayabilir. Turk J Clin Lab 2019; 10: 545-546.

- Editöre Mektup

\title{
Editöre mektup: Vücut kitle indeksi ile ortalama trombosit hacmi arasında herhangi bir ilişki bulunmayabilir
}

\section{Letter to the editor: There may be no relationship between body mass index and mean platelet volume}

\author{
Cengiz BEYAN'
}

'Ufuk Üniversitesi Tıp Fakültesi, Hematoloji Bilim Dalı, Ankara/TÜRKiYE

${ }^{2}$ Sağlık Bilimleri Üniversitesi, Keçiören Eğitim ve Araştırma Hastanesi, Iç Hastalıkları Kliniği, Ankara/TÜRKiYE

Anahtar kelimeler: beden kitle indeksi; kan trombositleri; ortalama trombosit hacmi; testlerin tahmin ettirici değeri

Key words: blood platelets; body mass index; mean platelet volume; predictive value of tests

Sorumlu Yazar*: Cengiz BEYAN, Ufuk Üniversitesi Tıp Fakültesi, Hematoloji Bilim Dalı, Çankaya, Ankara

E-mail: cengizbeyan@hotmail.com

ORCID: 0000-0003-1716-539X

Gönderim: 23.06.2019 Kabul: 03.07.2019

Doi: $10.18663 /$ tjcl.581475 
Karakurt ve arkadaşlarının çocuk ve adölesanlarda vücut kitle indeksi ile ortalama trombosit hacmi (MPV) arasındaki ilişkiyi inceleyen araştırmalarını büyük bir ilgi ile okuduk [1]. Yazarlar retrospektif olarak üç yıllık hastane verilerinden yararlanarak gerçekleştirdikleri araştırmalarında daha önce rapor edilmiş çaIışma sonuçlarından farklı olarak MPV değerinin zayıf olan gruba göre obez ve kontrol gruplarında daha yüksek bulunduğunu, ancak hepsinde de normal aralıkta olduğunu saptadıklarını ifade etmişlerdir. Biz bu çalışma hakkında yorum yapmak istiyoruz. Yazarlar iri trombositlerin daha aktif olduğunu, agregasyonda önemli olan tromboksan A2'yi daha çok ürettiklerini ve bu nedenle trombositlerin büyüklükleri ile fonksiyonlarının korele olduğunu ifade etmişlerdir. Ancak trombosit fonksiyonlarının belirlenmesi için altın standart test olan turbidimetrik metodun kullanıldığı optik trombosit agregasyonu ile ölçülen trombosit agregasyonu cevapları ile MPV dahil trombosit indeksleri arasında herhangi bir korelasyonun varlığı gösterilememiştir [2,3]. Yazarlar bir çok klinisyenin hemogram yorumlanmasında MPV değerlerini dikkate almadığını, halbuki güncel literatür incelendiğinde MPV değerinin sepsis, inflamatuar durumlar, kardiyovasküler hastalık riski, venöz tromboembolizm ve diabet gibi bazı hastalıklarda tanısal faydası olabileceğini belirtmişlerdir. Günümüzde MPV değerleri her ne kadar otomatik kan sayım cihazları tarafından tam kan sayımının bir parçası olarak rutin bir şekilde rapor edilse de, MPV ölçümü kanın alınması sonrası analiz yapılana kadar geçen süre, kullanılan analiz metodu, kullanılan antikoagulan, kullanılan otomatik tam kan sayım cihazının modeli gibi bir çok değişkene bağlıdır [4]. Etilendiamintetraasetik asit ile temas sonrası geçen süre ile MPV değeri önemli değişkenlik gösterir. Kanın alınması sonrası ilk iki saat içerisinde MPV değeri giderek artar ve farklı araştırmalarda bu artışın \%2-50 arasında değiştiği bildirilmiştir. Yazarla- rın düşüncelerinin aksine, trombosit sayısı, cinsiyet, yaş, etnik farkılıkların yanı sıra MPV ölçümünde kullanılan metodların standardize edilememiş olması nedeni ile MPV değerinin herhangi bir akkiz hastalıkta gerek tanı koymada, gerekse prognozu belirlemede bir rolü olamayacağı vurgulanmıştır [5].

Sonuç olarak, bu çalışmada ve farklı çalışmalarda vücut kitle indeksi ile MPV değerleri arasında olduğu düşünülen ilişkiye dair elde edilen çelişkili sonuçlar, çalışmaların retrospektif olarak planlanmasının da katkıda bulunduğu MPV ölçümünde kullanılan metodların standardize edilememiş olmasından kaynaklanıyor olabilir.

\section{Kaynaklar}

1. Karakurt N, Kendirci HVP. Çocuk ve adölesanlarda vücut kitle indeksi ortalama trombosit hacmini etkiler mi? Turk J Clin Lab 2019; 10: 247-50.

2. Ho CH, Chan IH. The influence of time of storage, temperature of storage, platelet number in platelet-rich plasma, packed cell, mean platelet volume, hemoglobin concentration, age, and sex on platelet aggregation test. Ann Hematol 1995; 71: 129-33.

3. Beyan C, Kaptan K, Ifran A. Platelet count, mean platelet volume, platelet distribution width, and plateletcrit do not correlate with optical platelet aggregation responses in healthy volunteers. J Thromb Thrombolysis 2006; 22: 161-64.

4. Jackson SR, Carter JM. Platelet volume: laboratory measurement and clinical application. Blood Rev 1993; 7: 104-13.

5. Noris P, Melazzini F, Balduini CL. New roles for mean platelet volume measurement in the clinical practice? Platelets 2016; 27: 607-12. 